\title{
A study of the potential of shore power for the port of Kaohsiung, Taiwan: to introduce or not to introduce?
}

\author{
Po-Hsing Tseng ${ }^{\mathrm{a} 1}$ and Nick Pilcher ${ }^{\mathrm{b}}$ \\ ${ }^{a}$ Department of Transportation Technology and Management, Feng Chia University, \\ Taiwan \\ b School of Marketing, Tourism and Languages, Edinburgh Napier University, \\ Edinburgh, UK
}

\begin{abstract}
To reduce ship emissions in port and city environments, cold ironing, or shore power has been suggested and implemented in many global advanced ports. Shore power is a land-to-ship electricity connection that allows ships to switch off onboard diesel-powered generators while docked. However, numerous challenges have prevented its implementation in many parts of the world. This paper explores these challenges as they have been experienced in the port of Kaohsiung (Taiwan). First, the comparisons of fiscal and environmental emission ( $\mathrm{NOx}$ and $\mathrm{CO}_{2}$ ) benefits when introducing shore power are quantitatively calculated for the future. Against the backdrop of these quantitative calculations, the results from qualitative, in-depth interviews with key stakeholders are presented and discussed. The quantitative calculations show that there are indeed significant fiscal, environmental and socio-economic emission benefits to be gained from introducing shore power in the long term; but that the implementation cost is high. Furthermore, the qualitative interview data show that perceptions of the current political and global economic climate, despite recognizing these benefits, arguably prevent such an introduction at the current time. Suggestions for future research and conclusions regarding considerations for the introduction of shore power for port authorities and governments to consider are made.
\end{abstract}

Keywords: Shore Power, Port Sustainability, Emission

\section{Introduction}

With international shipping now carrying over $80 \%$ of world trade by volume, the industry's greenhouse gas emissions attract increasing public attention (Gilbert and Bows, 2012; Yap and Lam, 2013). Ships are recognized as major air polluters, with associated climate change, and adverse socio-economic and health-related impacts as well (Liu and Tsai, 2011). Shipping activities at port are highly pollutive (Ng and

\footnotetext{
${ }^{1}$ Corresponding author's address: Department of Transportation Technology and Management, Feng Chia University, No 100, Wenhwa Road, Seatwen, Taichung 40724, Taiwan. Tel.: +886 4 24517250; Fax: +886 4 24520678. E-mail address: phtseng@fcu.edu.tw
} 
Song, 2010; Acciaro, 2014), and over 95\% of the world's shipping fleet is diesel engine powered, with even modern marine engines producing higher emissions per power output than regulated on-road diesel engines. When docked at berth (in hotelling), ships still need internal generators for basic functions, such as lighting, chilling, refrigeration, cooling, heating, pumps, fans, emergency equipment, elevators and so on. Given recent changes in the nature of trade, such as the increase in container transport of refrigerated perishable goods, such energy demands are also increasing (Wilmsmeier et al, 2014). In Taiwan, most ships at berth use heavy fuel oil for both main and auxiliary engine power and boiler operations, creating dangerous air pollution (Liu and Tsai, 2011) with potentially serious adverse consequences on health. In the long-term this is not desirable or sustainable and an effective mitigation and control strategy needs to be adopted to reduce emissions from ships at berth (Ko and Chang, 2010; Vergara et al., 2012; Acciaro, 2014), ideally as part of a coordinated port energy management strategy (Acciaro et al, 2014; Wilmsmeier, 2012). In some advanced ports (e.g. in California, US), regulations mean that ship owners must follow strict environmental protection regulations and port authorities forbid ships to operate their prime movers whilst at berth (Khersonsky et al., 2007).

In order to reduce emissions in the port, solutions such as retrofitting ships' engines for LNG (Acciaro, 2014) and shore power are viewed as useful strategies (Kim et al., 2012; Lam and Notteboom, 2014; Liu et al., 2014). Shore pPower increases sustainability and reduces the environmental impact of shipping activities at berth (Khersonsky et al., 2007; Salomon, 2009; Ferrara et al., 2011; Yang et al., 2011; Theodoros, 2012). Shore power, also known as 'cold ironing', 'alternative power supply', 'shoreside power', and 'onshore power', reduces air pollution from ships in the port area through electric feed to the ships from onshore (Zis et al., 2014). It is a land-to-ship electricity connection that allows ships to switch off onboard diesel-powered generators while docked. Shore power entails three basic components: a shore-side electrical system and infrastructure, a cable management system, and a ship-side electrical system. Environmental and socio-economic benefits are improved air quality, reduction in noise, and reduced health concerns from shipping activities at berth. Yet, despite these environmental benefits, shore power is not at present implemented as a matter of course, as a number of challenges remain.

Theodoros (2012) has investigated the implementation of shore power and strategically analyzed its benefits. Theodoros found that from an environmental point of view the benefits are significant, but that financial challenges remain (cf. Acciaro's (2014) conclusions regarding LNG). Shore-side electrical power has been found to 
achieve significant carbon dioxide $\left(\mathrm{CO}_{2}\right)$ reductions where it has been used: 99.5\%, (Oslo, Norway) 85.0\% (France) and 9.4\% (Fort Lauderdale, US) (Hall, 2010). Shore power systems have been established in North America (Los Angeles, Long Beach, Juneau, Vancouver and Seattle) and Europe (Gothenburg, Lubeck, Antwerp) in the past decade. Chang and Wang (2012) indicated that $\mathrm{CO}_{2}$ and Particulate Matter (PM) emissions could be reduced by $57.16 \%$ and $39.4 \%$, respectively, if adopting an onshore power supply system in Kaohsiung port. Further, based on ship-call data from six regions (West Coast, USA; East Coast, USA; North Sea, UK; Australia, Australia; Mediterranean, Greece; North Sea, Germany), Zis (2014) examined port emissions reduction policies. Zis's results found that shore power for all berthing vessels can reduce in-port emissions by $48-70 \%, 3-60 \%, 40-60 \%$ and $57-70 \%$ for $\mathrm{CO}_{2}$, Sulfur dioxide $\left(\mathrm{SO}_{2}\right)$, nitrous oxide ( $\left.\mathrm{NOx}\right)$ and black carbon $(\mathrm{BC})$, respectively. In short, although environmental and socio-economic benefits are significant when adopting shore power, cost considerations and managing the complex and varied grant requirements are the two main challenging barriers. ${ }^{2}$ Where shore power has been introduced this is often due to governmental drive and initiative as part of a wider and longer term green port strategy.

Taiwan is highly dependent on foreign trade. More than 99\% of Taiwan's total international trade in terms of weight is attributable to marine transport ${ }^{3}$, and Taiwan has become a pivotal point for shipping lines crossing the Pacific Ocean. Consequently, Taiwan has developed three main international ports, Kaohsiung being the gateway city port to Taiwan and accounting for about $54 \%$ of total national ship calls, and, as of 2014, having 145 terminals in the port. According to the Taiwan International Port Corporation, ${ }^{4}$ there were 17,308 ship calls in the port of Kaohsiung in 2014, equivalent to 47 ships per day. In relation to shore power, three shipping companies have installed shore power equipment (in terminals 96, 108-111 and 115-117) there. Yet, only a few of their own company ships use the equipment and take up is minimal. Such a system, as we quantitatively show here using Kaohsiung as an exemplar, has great potential for improving port sustainability and reducing environmental impact. However, as our qualitative results show, many implementation barriers within the practical policy arena exist; of geo-strategic, financial, and also technical natures (e.g. voltage, plug standardization and regulation). To date, however, despite a knowledge of many of these barriers existing, surprisingly little effort has been devoted by port authorities and port operators to suggest ways

\footnotetext{
2 Jill, B.B., Ibrahim, M. Leong, T., Prevost, D., Sandifur, M., Sinkoff, R. Port of Oakland completes shore power project's first phase, Port Technology International, http://www.porttechnology.org/

3 Transportation Research Statistics http://www.iot.gov.tw/

${ }^{4}$ http://163.29.117.5/english/index.htm
} 
forward to reduce or mitigate against them. Our results complement those of other researchers in the case of Europe (Arduino et al, 2011) and show that, once multiple perspectives and stakeholders are consulted (cf. Acciaro et al. 2014) despite all the positives to be gained from shore power, without strict governmental led policy and legislation, perhaps as a wider policy of port differentiation (Wilmsmeier, 2012) it is unlikely shore power will be adopted. This is despite the positive views of shore power from the perspectives of the government officials interviewed here.

The paper is organized as follows. After this brief outline of the problem here in the introduction, section 2 describes the methodology used in the data collection and analysis. Section 3 presents the quantitative analysis and the qualitative results from in-depth qualitative interviews with port management and government officials. Finally, discussion and conclusions and policy implications that draw together the key issues are presented in section 4, and key issues for stakeholder discussion in any introduction of shore power systems are brought together in Appendix A for practical use by policy makers.

\section{Methodology}

\subsection{Quantitative approach}

In this section, two types of analysis are illustrated: cost comparison of shore power adoption, and potential emission reduction effect in the port of Kaohsiung.

\subsubsection{Cost comparison for diesel fuel-powered auxiliary engines and shore power}

We conducted a cost analysis based on data of current electricity costs we gathered from a combination of participant conveyed figures from the interviews we conducted, and from sources such as the Taiwan International Port Corporation. To contextualise and understand the cost comparison between conventional terminals and shore power terminals, we considered both fuel and electricity costs (with extra costs when implementing shore power).

We assume 100 containerships (in 8,200 $\mathrm{TEU}^{5}$ ) calling at one terminal in Kaohsiung port in one year. Fuel consumption for such a containership is 0.8 tons/hour and average time at berth is 16 hours/ship. The fuel consumption would be $12.8(=0.8 * 16)$ tons/berth-hour. The estimation of fuel cost is therefore 7,680

\footnotetext{
5 Twenty-foot Equivalent Unit. Based on interview data, containerships are viewed as a high priority to adopt shore power in Taiwanese ports in near future. Moreover, 8,200 TEU containerships are a common containership type in the Port of Kaohsiung. Although the 100 containerships (in 8,200 TEU) are merely assumed in this case, this figure can be adjusted for possible scenario analysis. Nevertheless, the wider picture of other type ships undoubtedly merits further comparative study for future research.
} 
$(=12.8 * 600)$ US\$/ship/year, assuming fuel price is 600 US\$ dollars/ton. ${ }^{6}$

Regarding shore power electricity costs, the electricity rate is negotiated case-by-case, according to our interview data ${ }^{7}$. We assume the electricity rate is 0.1US\$ (per $\mathrm{kWh}^{8}$ ) for users. It is assumed that each containership uses 50,000 kWh. The electricity cost would therefore be 5,000 $(=50,000 * 0.1)$ US\$ dollars/ship. The extra costs for shore power include equipment, operation/maintenance, and extra charges when electricity volume exceeds the contract quota. Assuming the design life for a containership is 20 years and the equipment cost of shore power is 17.8 US\$ million US\$, ${ }^{9}$ the construction cost of shore power can be estimated to be 8,900 US\$ million (=17.8 US\$ million/20/100) dollars per ship, assuming an annual 100 containership calls at one terminal. The operation/maintenance cost is estimated to be 700 dollars/ship/year. ${ }^{10}$ The extra charge for exceeding the quota is a variable cost and uncertain; it is therefore difficult to estimate and not included in our cost comparison.

\subsubsection{Estimation of pollutant emission reduction}

This section details a scenario study that was undertaken to illustrate the emission reduction effect when adopting shore power in the container terminals in the port of Kaohsiung. ${ }^{11}$ The time spent in hotelling mode by each individual containership from January 2014 to December 2014 within the study sample was calculated in hours, and begins when a ship ties up at berth, and ends when it leaves that berth. The arrival and departure times were obtained from Taiwan International Ports Corporation. The total number of containerships that called at the ports of Kaohsiung in 2014 was 8,458. ${ }^{12}$

Based on Adamo et al. (2014), the auxiliary engine average power (AP) consumption during hotelling was obtained by considering gross register tonnage, power tonnage ratio and load factor. The calculation equation is shown as follows:

\footnotetext{
${ }^{6}$ Assuming 30 NT dollars is 1 US\$ dollar. The computation figures (e.g., fuel consumption, average time at berth) come from interviews in Chinese Petroleum Corporation in Taiwan and Taiwan International Ports Corporation.

7 The actual electricity rate is undecided, but it is similar for general commercial or industrial use.

${ }^{8}$ kilowatt-hour (kWh). Based on interview from Taiwan Power Company in Taiwan and Liu et al. (2014).

${ }^{9}$ The cost of shore power would be various in other countries due to equipment grade. This figure is based on Liu et al. (2014).

${ }^{10}$ From interviews with Taiwan International Port Corporation.

11 Assuming the shore power style is similar to the port of Taranto (Italy) (Adamo et al., 2014).

12 According to the Ministry of Transportation and Communication (http://www.motc.gov.tw/en/index.jsp), Kaohsiung port is equipped with 25 container terminals. The number of containerships and container throughput in Kaohsiung port were responsible for $50.4 \%$ $(=8,458 / 16,785)$ and $70.4 \%(=10,593,335$ TEU/15,050,514 TEU) in all Taiwanese international ports in 2014, respectively.
} 
Where:

$\mathrm{AP}=$ average power consumption during hotelling

GET $=$ Gross Register Tonnage (tons)

$\mathrm{PTR}=$ Power tonnage ratio ( $\mathrm{kW} /$ tons $)$

$\mathrm{LF}=$ Load factor for auxiliary engine

Based on past studies (Ericsson and Fazlagic, 2008; Browning and Bailey, 2006; Jeseph et al., 2009), the value of PTR and LF are $0.2 \mathrm{~kW} /$ tons and 0.17 , respectively. Two pollutants ( $\mathrm{NOx}$ and $\mathrm{CO}_{2}$ ) were considered to estimate potential emission reductions when referring to related parameters from Adamo et al. (2014). Thus, the estimate of $\mathrm{NOx}$ and $\mathrm{CO}_{2}$ reduction for one year when implementing shore power at berth can be expressed as:

$\mathrm{ER}_{\mathrm{i}}=\mathrm{AP} \cdot \mathrm{AR} \cdot 365 \cdot 24 \cdot \mathrm{ERF}$

Where:

$\mathrm{ER}_{\mathrm{i}}=$ Emission reduction where $\mathrm{i}=1,2$ in line with the pollutants addressed within the study $\left(\mathrm{NOx}, \mathrm{CO}_{2}\right)$

$\mathrm{AP}=$ Average power consumption during hotelling

$\mathrm{AR}=$ the adoption rate of shore power at berth (\%)

$\mathrm{ERF}=$ the specific emission reduction factor $(\mathrm{g} / \mathrm{kWh})$ where $\mathrm{ERF}_{\mathrm{NOx}}=11.8 \mathrm{~g} / \mathrm{kWh}$ and $\mathrm{ERF}_{\mathrm{CO} 2}=700 \mathrm{~g} / \mathrm{kWh}^{13}$

\subsection{Qualitative approach}

During the period of May-June 2014, we conducted in-depth interviews with 12 key stakeholders (7 government officials and 5 port operators). Government officials (7) had an average of 13 years' experience, ranging from 7 to 20 years, and their job types included director, senior deputy director and supervisor. Port operators (5) had an average of 18 years' experience, ranging from 12 to 20, and their job types included senior director, junior vice president, manager and senior engineer. We chose to use interviews rather than broader sweeping methods of questionnaires as we wanted access to the in-depth views that interviews would give us. Although questionnaires provide a broad range of data and access to many views, they ignore the essentially social nature of language (Voloshinov, 1973) and do not allow for dialogue (Bakhtin, 1981). This can often bias results through resistance on the part of participants to complete the questionnaires accurately (Galasiński and Kozłowska, 2010). In contrast, in-depth interviews, although not allowing access to as many participants for logistical reasons, allow for further dialogical exploration of perceptions, and as a result they were the method chosen given that this is precisely

13 The values were adopted from Trozzi and Vaccaro (1998) and Commission Recommendation 2006/339/EC (2006). 
what we wanted to achieve.

Interviewees were chosen strategically from port management (including private and public shipping companies) and government. To ensure participants were able to convey information in a linguistic medium they were comfortable with, interviews were conducted in participants' native language (Cortazzi et al., 2011). To ensure accuracy these interviews were recorded (on average 30 minutes) and transcribed verbatim so no details were omitted by the interviewer (who transcribed them). Then, considering the need for an appropriate translation, the interview transcripts were translated into English using a goal oriented or 'skopos' approach (Vermeer, 2004), rather than a literal approach, and were verified for readability by a native English speaker. This was done to help reach as natural a translation as possible. To ensure as far as possible that participants were protected and therefore felt at ease to give what would be more valid data, ethical approval was granted from the appropriate bodies and anonymity assured (Christians, 2011). Interviews were 'active' (Holstein and Gubrium, 1995) in the sense that negotiation of meaning was allowed through the use of a 'spider diagram' (cf. Pilcher et al., 2013) that focused on key issues (see Appendix B) developed from the literature as a graphic to provide a focus for 'conversation pieces' (Sevdung and Rasmussen, 2002). This is in contrast to a list of questions which could have biased the meaning according to the perceptions of the interviewer having predetermined their linguistic form in the direction of a particular bias (cf. Qu and Dumay, 2011). Transcripts were analyzed using a constructivist grounded theory approach (Charmaz, 2011) where themes and issues emerged rather than their having been pre-determined. This approach ensured that, rather than trying to pigeonhole the data into pre-arranged categories as an objectivist grounded theory approach would have done, we were able to see themes emerge that we had not anticipated but which are of fundamental importance to consider. We now present and discuss our results.

\section{Results}

\subsection{Quantitative cost analysis}

3.1.1 Cost comparison of shore power and conventional terminal

Based on section 2.1.1, the cost comparison between a conventional terminal and a shore power terminal is shown in Table 1. The results show that an extra annual 6,920 US\$ will be paid if containerships used shore power terminal and conventional terminal are replaced. 


\section{Table 1}

Annual cost comparison of conventional and shore power terminal

\begin{tabular}{lcc}
\hline Comparison & $\begin{array}{c}\text { Conventional } \\
\text { terminal }\end{array}$ & $\begin{array}{c}\text { Shore power } \\
\text { terminal }\end{array}$ \\
\hline Fuel cost (US\$/ship)* & 7,680 & 5,000 \\
\hline Electricity cost (US\$/ship) & 8,900 \\
\hline Equipment cost (US\$/ship) & 700 \\
\hline $\begin{array}{l}\text { Operation/maintenance cost } \\
\text { (US\$/ship) }\end{array}$ & 14,600 \\
\hline Sub-total & 7,680 & 6,920 \\
\hline Difference & & \\
\hline $\begin{array}{l}\text { Note: } * \text { Fuel consumption for ship is 0.8 tons/hour and average time at berth is 16 hours/ship. } \\
\quad \text { Fuel consumption is 12.8 tons/berth-hour and fuel price is 600 US\$ dollars/ton }\end{array}$
\end{tabular}

In addition, another reason that shore power is not adopted in the terminal is that ship owners would not use shore power in older ships due to the high expense of installing ship-side equipment. ${ }^{14}$ Thus, the high capital costs of shore power make it unattractive. In addition, overall life-cycle costs are not easily evaluated.

\subsubsection{Potential pollutant emission and environmental cost reduction}

Applying the model described in the equation (1) and (2) in 2.1.2, estimates of pollutant reduction ( $\mathrm{NOx}$ and $\mathrm{CO}_{2}$ ) when implementing shore power in the port of Kaohsiung are calculated. According to Berechman and Tseng (2012), the environmental cost of NOx and $\mathrm{CO}_{2}$ in the port of Kaohsiung are US\$ 4,991 and US\$ 26, respectively. Using the year 2014 as a baseline, we consider a scenario of the adoption rate of shore power at the pace of $10 \%$ of market share in the container terminals in the port of Kaohsiung per year. Thus, the values of AR are 20\%, 40\% and 60\% for 2016, 2018 and 2020, respectively. As shown in Table 2, NOx and $\mathrm{CO}_{2}$ could be reduced by 428 and 25,391 tons in 2020, respectively. With regard to environmental benefit, it would achieve US\$ 2,136,148 and US\$ 660,166 benefit for NOx and $\mathrm{CO}_{2}$ in 2020, respectively.

\section{Table 2}

The NOx and $\mathrm{CO}_{2}$ reduction effect by adopting shore power

\begin{tabular}{cccccc}
\hline Year & $\begin{array}{c}\text { Market share } \\
\text { of adoption } \\
\text { shore power } \\
(\%)\end{array}$ & $\begin{array}{c}\text { NOx } \\
\text { reduction } \\
\text { (ton/year) }\end{array}$ & $\begin{array}{c}\text { NOx } \\
\text { environmental } \\
\text { cost reduction } \\
\text { (US\$/year) }\end{array}$ & $\begin{array}{c}\mathrm{CO}_{2} \text { reduction } \\
\text { (ton/year) }\end{array}$ & $\begin{array}{c}\mathrm{CO}_{2} \\
\text { environmental } \\
\text { cost reduction } \\
\text { (US\$/year) }\end{array}$ \\
\hline 2016 & 20 & 104 & 519,064 & 8,464 & 220,064 \\
\hline 2018 & 40 & 285 & $1,422,435$ & 16,928 & 440,128 \\
\hline
\end{tabular}

\footnotetext{
14 From interviews with Taiwan International Port Corporation, expense of installing ship-side equipment per ship is about 3.3 million US\$ in Kaohsiung port.
} 


\begin{tabular}{llllll}
\hline 2020 & 60 & 428 & $2,136,148$ & 25,391 & 660,166 \\
\hline
\end{tabular}

Note: the year of 2014 is the baseline.

Currently, the investment and budget planning of shore power in Taiwan are organised by Taiwan International Ports Corporation. The deployment quantity and schedule will depend on stakeholders' opinions (e.g. shipping companies, port regulator, Taiwan Power Company, etc). Overall the shore power users are mainly concerned about the impact on the electricity rate since this affects their operation costs in the terminal. According to Yeh et al. (2013), the electricity rate of a kilowatt hour for shore power (including electricity and installment cost) in Taiwan is US\$ 0.21 . In contrast, if a ship generates electric power by burning fuel, the electricity rate of a kilowatt hour for heavy fuel is a significantly lower US\$0.13. Therefore, there is US\$ $0.08(=0.21-0.13)$ increase per kilowatt hour electricity if a ship adopts shore power. Nevertheless, this difference could be resolved by subsidy from governmental funding or through particular financial mechanisms (such as an Emissions tax).

To complement and contextualize these quantitative results in the practical arena we now present and discuss the perspectives of the government officials and port managers we spoke to in our in-depth qualitative interviews.

\subsection{Qualitative analysis and discussion.}

We group the results from the in-depth qualitative interviews into two sections. These two sections are entitled motivation and timescale, and issues and concerns. The latter issues and concerns section we further subdivide into: costs, profits, and funding; specific electricity costs and; technical issues and solutions. We present the data from the government officials (named, or denoted as GO) and port officials (named, or denoted as PO) together but highlight differences where we believe they are relevant. In this section, we attempt to present the findings in the form of a readable analytical narrative account. In order to do this, we interweave our interview results with the discussion of them.

\subsubsection{Motivation and timescale}

In terms of the motivation for shore power, our qualitative interview data show considerable overall enthusiasm. Port operators felt shore power part of an international trend, for exampleemplar "This is an important trend for developing green port and green ship.” Further, port operators sometimes expressed urgency regarding its introduction: "it should be done early. It has already been developed in Hong Kong, Singapore, LA and Seattle port. Our pace is too slow... if we do not do it 
today, we will regret this tomorrow.” Equally, many government officials were also enthusiastic about shore power-similarly, both locally, as "it is the green port trend and we must reduce air pollution (e.g. $\mathrm{SO}_{2}$ )" and globally, as "it is also the international trend." Shore power was thought to help reduce a number of socio-economic and environmentally related aspects such as air pollution, noise pollution, and improve port safety. Nevertheless, it was believed to be essential to introduce shore power 'globally' and not simply to a certain place as "if we just do it in a certain place, it will not be enough..., we can not achieve any significant effect this way" and that "ships emissions at port are just one part of the total causes of pollution.” Yet, balancing these positive desires for shore power, there was also the concern that "it must not affect trade and economic development in Taiwan.” There were thus a number of tensions revealed in the data from the interviews: firstly, between specific and wider coverage, secondly, between the need to start somewhere, but also to have a wide impact, and thirdly, in a desire to be environmental but at the same time profitable. Most significantly perhaps though, no-one was opposed to introducing shore power, despite the fact that the aspects and issues raised would need to be taken into consideration when introducing any shore power systems.

Regarding timescale, and as to exactly when shore power would be operational in Taiwan, Government officials felt that it would be in place on average in about 10 years' time. For exampleemplar, "it may be 10 years later," or simply, "in the future.” Similarly, one port operator felt, "It may take 7-8 years." Nevertheless, it was often the case that provisos were added to projected timescales, for exampleemplar that it would depend on new ships or laws, or that it would be too expensive to equip old ships, which, “can be used for 20-30 years” (PO). One government official also spoke of the salience of technical issues: "It depends on the deployment progress of shore-side equipment." Other government officials spoke of a purely political drive being the key influential factor in any introduction: "It depends on government department's arrangement and attitude," or of the idea that political and global factors would be of importance:- "itt is difficult to say. It depends on the rule of law and also must consider the foreign ship's inclination. We do not know what this is now.” Here then, the importance of both technical and political factors was noted in terms of how quickly shore power would be introduced. Notably, the in-depth qualitative interviews helped reveal the clear interconnectivity of these aspects. Thus, without the political willpower and motivation to introduce shore power it is unlikely to happen, as this is needed to help overcome the technical challenges and to drive shore power forward.

Regarding the likelihood of shore power being introduced, it was often felt that the introduction of shore power was inevitable. Government officials felt, "it is a global trend... Taiwan will also do it in the future," or that "new ships will be constructed to 
be equipped with shore power facilities.” Further, Port Operators said that, “itt is OK regarding technical issues. Our new ships are built by Taiwan Ship Construction Company and are already equipped with shore power facilities.” Yet, here again many underlying tensions and issues were revealed. Firstly, if ships called only at developing countries ports and not those of Europe or the US, "they do not care about environmental issues, whereas we will worry about shore power questions:” (PO). Further, from a technical perspective, although new ships were equipped to access shore power, to refit older ships so they could access shore power was unfeasible: "the engineering cost is huge when renewing old ships... it is not worth doing it after evaluating the installment cost" (GO). There was thus a tension between the 'inevitable' introduction versus the 'no need', and also between technically advanced new ships promoting shore power usage versus the continued use of older ships preventing it. Notably, government officials' comments were mostly non-commital and also generally vague and rhetorical. This would suggest that although officials perhaps felt a need to say shore power would be introduced, they equally were unable to commit as to exactly when, as without actual legislation from the government it will arguably not be introduced.

\subsubsection{Issues and concerns}

\subsubsection{Costs, profits, and funding}

Understandably, the issues of the cost, and the resultant impact upon profit, of introducing shore power were key. Generally, costs were noted to be both fixed and variable: "The fixed cost includes shore facility, the variable cost includes electricity fee, operator's cost, and maintenance cost.” (GO). One government official believed ship owners should pay some of the fixed costs, on the ship-side: "the fixed cost includes electricity facility on shore, ship-side electricity facility, and reel facility. The ship owner is usually responsible for ship-side facilities and reel." Regarding the amount of these fixed costs, occasionally an actual price was given, for exampleemplar: "țThe installment cost of ship-side shore power facility is about one million NT dollars” (GO). It was also noted that such shore side costs were higher than those on the ship-side: "The shore-side facilities are more expensive than the ship-side facilities-" (PO). It was also noted how the fixed costs involved in shore power could be divided into, "ship facility, terminal facility, line pipe, electricity factory... further maintenance, and human cost” (GO).

In terms of how port operators approached the issues of costs, perhaps understandably, profitability was key, for exampleemplar one port operator said that, "public welfare policy is always conducted when the corporation has made a profit." 
Port operator perspectives with regard to cost were to combine affordable fuel with discounts from government subsidies: "We can not expect very low fare, but we should be competitive with other ports (e.g. Hong Kong, Singapore, LA)... fare benefit and discount would increase the adoption rate. Indeed, Los Angeles port in the US has already introduced it” or that, “yes, business concerns are of revenue and cost issues... we hope the government can provide a subsidy for shore power users and low sulphur fuel users."

Regarding profit, similarly to port operators, government officials also focused on the key issue of not wanting to discourage shipping companies from calling at Taiwanese ports due to prohibitive costs. For exampleemplar, "if we have too many regulations and produce extra costs, the shipping operators will choose other countries...there should be a subsidy provided for the operators. Otherwise, very few operators will adopt it" (GO). Nevertheless, one official believed that the ports would still be profitable and that shipping companies should follow regulations: "țThere still remains market competitiveness in Taiwan. If the ship owners would like to run a business, they must obey the port regulations in Taiwan.” The sensitivity of cost was therefore a key issue and something that must be decided on before the implementation of any system. Government officials were clearly aware of the need to be very careful in not discouraging ships from calling at ports due to prohibitive costs, as were port operators. The idea of costs being competitive and comparable with those of ports elsewhere in the world was noted, and the idea was also mentioned that in order to help create a 'cultural' change in the uptake of shore power, discounts and subsidies would greatly help, although government officials were divided on whether subsidies should be created. These are thus key aspects to be decided on before any shore-power systems are introduced.

On the funding of shore power, many government officials felt an emissions tax could provide subsidies to set up shore power. For exampleemplar that shore power, "must rely on governmental subsidy. For exampleemplar, using an emission tax to subsidize shore power operators." Yet, as well as subsidies, as hinted at above in relation to costs, government officials also leaned toward regulations. For exampleemplar, one view was that a schedule must be introduced with a 'sunset clause' for ships to adhere to, as had been done with truck regulation in Taiwan's ports, and that, "when the expiry date becomes due, operators can not continue to use the ship in port." or that "we must adopt environmental protection rules to ask ship owner to install shore power in the future.” It was also felt that without regulating to create the 'convention' for shore power, even if new ships were equipped to use shore power, 
they would not: "even if all old ships are replaced, they would not conduct shore power overall. If there is no convention to conduct shore power, it is difficult to conduct it. If this is a regulated policy, however, everyone will conduct it.” Nevertheless, regulation for shore power transpired to be highly complex; one government official noted that in terms of inter-departmental coordination at a government level, different departments needed to coordinate more effectively: “țThe Transportation Administration thinks it should be subsidized from the Environmental Protection Administration. The Environmental Protection Administration thinks it involves the electricity issue, which is subordinate to Economic Affair Administration. These three sections do not have any consistent common view. The Harbor and Marine Technology Center (Government department) is investigating this issue now."

Thus, here again the complexity of the introduction of any shore power system was evident. Echoing the idea that shore power was 'not necessary' (above), here, the possibility of it not being used even if available was noted. It was noted that shore-power take-up would involve a complex 'cultural' change in berthing practices, something which would need to be created. Further, much discussion around how to fund shore-power is clearly needed, and regarding decisions whether to subsidize shore power, or whether to facilitate it through regulation alone. Further, given the different views of the different agencies, decisions need to be made regarding exactly who should fund shore power, i.e. which government department should be responsible for it. Arguably, this is a decision that would have to be made at a level higher than these departments, unless it was agreed that the costs could be split between the three of them. Yet, amongst government officials, there was a general feeling that although the cost was high, the importance of following the 'international green port trend' was greater: “ifn fact, it is cheaper to use ship fuel compare to shore power system, but, we must follow international green port trend to adopt shore power. We must invest lots of money to do it." (GO). Thus, the environmental and socioeconomic benefits of shore power were recognized and championed. Yet, there were many aspects here that needed to be resolved before any legislation can be introduced, and, arguably again, without any legislation, shore power will not be introduced and will not be taken up. At the moment, the lack of any final decisions on these issues, coupled with the fact that it is unclear which department is responsible for any decisions, means that any legislation is unlikely to be implemented.

\subsubsection{Specific electricity costs}

In terms of specific electricity costs, the actual price that would be charged for the electricity was also a key issue. For many government officials, this was an unknown, 
or as yet, uncalculated cost. For exampleemplar, "we do not know it now" or, "the fare of electricity is not decided because it must consider overall cost, including installment and maintenance. It is quite difficult to do it and it is currently under research." Regarding whether the cost would be higher than the traditional industry/household electricity fare, one government official noted it would be higher than household electricity, whereas one port official felt it would be, "cheaper than traditional electricity fare." Also, one government official felt it would be significantly cheaper than conventional ports in terms of energy costs: "gGenerally, the cost of shore power electricity is just $25 \%$ of conventional terminal fuel costs:" (GO). Notably, both voices amongst the government officials and port operators felt there needed to be further discussion. For exampleemplar: "țThe electricity fare standard should be discussed among ship owners, port authorities and power suppliers" (GO) and "the total cost is difficult to estimate and needs further discussion with different departments” (PO).

Thus, the cost of the electricity is as yet undecided, and this needs to be considered. Further, we argue, it needs to be considered alongside the other issues discussed here, such as the need to retain profitability, encourage a 'cultural' change toward the use of shore power, and involve all stakeholders in any discussion, to decide beforehand on which department is to be responsible, and to decide on how much (if anything) should be given in terms of subsidies. The decisions taken on all these issues will inevitably affect the uptake of any shore power system and be of critical importance to its success, given that all such issues need to be resolved and decided upon before any legislation can be introduced.

\subsubsection{Technical issues and solutions}

In addition to issues related to costs, a number of technical issues arose. With these issues, there was often one side, or 'voice' of 'caution', that recommended caution and emphasized the challenges involved, but another 'voice' of 'calm' that felt the issue to be not serious. For exampleemplar, regarding plugs and connection types, the 'voice' of 'caution' noted that 'the connection between ship and shore is not unified... as I know, there are four types of connections, and maybe more, but it would be great if there was only one type of connection.” (GO) Similarly, that such variety in connection types was, "dangerous for facility and operators in the terminal” (GO) and that ship length would determine where the connector could be placed and where the ship could berth. Yet, the 'voice' of 'calm' said of differing plug and connection standards, that, "this problem is not serious" (GO). Further, regarding voltage, one port operator expressed a ‘voice’ of ‘caution’: “łoltage can be separated 
into $280 \mathrm{~V}, 385 \mathrm{~V}, 445 \mathrm{~V}$ and so on. Therefore, the power supplies need to be different. Different types of ship must be provided by various voltage powers.” (PO) Similarly, one government official said that, "based on the trend of international shore power installment, the power voltage could be $6.6 \mathrm{KV}$ or $11 \mathrm{KV}$. Therefore, this kind of power is too high a voltage for Taiwan's case” (GO). Further, the voices of 'caution' noted with regard to ship facilities that new ships were easily able to access shore power, for exampleemplar, "it is very common in new ships, but older ships would not adopt it due to cost considerations" (GO) and also, "our new ships which are built by Taiwan Ship Construction Company are already equipped with shore power now" (PO). Regarding the technical issue of the time required to set up the shore power supply after berthing, a voice of 'caution' noted that, “it needs the operation time to plug in the facility. It usually takes 1-2 hours. I even hear up to 5-6 hours if there are some problems when ships plug it." Or that "each side (ship and shore) must test the electricity power before plugging in to the facility, for reasons of safety.” In contrast, a voice of 'calm' noted that: "îtt will not spend much time if the port facilities are good.”

Thus, technically, similarly as is the case with almost all of the issues above, a number of aspects need to be clarified with any introduction of shore power: voltage types, connection types, connection lag times. These aspects, we argue, need to be considered in the context of costs and responsibility.

In addition to the issues and concerns noted here, solutions were also suggested. One solution was to use solar energy and then sell any extra power to Taiwan Power Company: "s Shore power should tie in a solar energy facility to store electricity and then sell it to Taiwan Power Company" (GO). Also, the process and steps to introduce shore power were suggested: "the public terminal could do it first and set a fine exampleemplar. The containership could use it first and the new terminal will then prepare line pipes for future shore power construction.” (GO). Or even that it should be carefully considered whether shore power was in fact necessary, as it may in fact not be required if LNG ships become the norm: "maybe the Liquefied Natural Gas ship will become popular in the future, and in this scenario the situation of adopting shore power becomes unimportant.” (GO). One port operator also underlined the need to consider the introduction of shore power as one of six key factors: "The first is cargo source. The second is that the port facilities must be good. The third is shore power. The fourth is the port fees must be reasonable. The fifth is that ships can be refueled and water refilled and that a secure environment (no terrorist) is provided. The sixth is that cargo transshipment is good. The model exemplar is Singapore” (PO). 
There were therefore numerous solutions suggested: to introduce step by step, to sell extra power, and to consider shore power as part of a total solution. It was also noted that shore power may not be necessary should LNG powered ships be used (cf. Acciaro, 2014), which itself could either be a partial or a total solution. Similarly here as well then, the complexities are such that it will arguably take a long time to work through them and arrive at any decisions for legislation.

\subsection{Discussion}

The quantitative calculations detailed here show the long-term potential of shore-side power to improve the environment and socioeconomic conditions through reductions in port emissions. Further, the qualitative interviewee data shows an overall feeling of enthusiasm for shore power in terms of its positive impacts on the environment and in terms of improving the health related aspects of the port. Nevertheless, t. The data combined also shows four key challenges exist. First, the cost of installing shore power may well be unattractive for port authorities: construction costs include power lines, cables, reels, transformer deployment, building in additional electrical capacity, conduits and plug infrastructure. Meeting these costs may represent a significant financial burden compared to simply adhering to the status quo of traditional ship diesel, and the costs differ considerably according to location and modernity of the ports concerned. Arguably, only higher-level national government legislation and policy commitment can surmount this challenge.

Second, ascertaining the necessary capacity for the shore power is problematic as power requirements differ greatly, depending on ship type, size, and number of refrigerated containers on board. Furthermore, connectors and cables are not internationally standardized and voltage issues also arise when designing shore-to-ship connection in port as no global uniform voltage and frequency requirement and standardization of electricity exists. For exampleemplar, the port power system in Taiwan is usually $50 \mathrm{~Hz}$, but is $60 \mathrm{~Hz}$ in North America and Japan (Jia-Sheng et al., 2012). Again, we argue, without higher-level governmental drive and legislation, these issues will remain unresolved.

A third challenge is to meet system design requirements and safety stipulations, and IEEE/ISO/IEC standard P80005-1 (engineering and electrical standard) must be followed. Fourth, no global regulations and legislation of shore power exist, and advanced ports (e.g. Los Angeles and Long Beach) have stricter legislation to regulate air quality. Thus, cost estimations cannot be exact and can only be a 'guesstimate'. Here again, given this uncertainty, the need for government funding or legislation to 
override any loss to port operators or shipping companies is needed for any successful introduction of shore power.

Our qualitative interview data also revealed a number of novel aspects that stakeholders and policy makers should discuss and consider to help facilitate and focus decision making regarding the implementation of and management of shore power systems. Cost wise, issues of whether to subsidize shore power or to regulate (Khersonsky et al., 2007; Arduino et al., 2011) for it; whether to subsidize it through an emissions tax or otherwise; further, exactly who should pay for what aspect of the facilities; what the exact cost for the electricity will be, and the desire to maintain port competitiveness yet be environmental. These again are issues that need to be decided at a higher-level by national legislation.

\section{Conclusions and Policy Implications}

Through an investigation using the port of Kaohsiung as an exemplar, this paper considered the feasibility of introducing shore power to electrically power ships at berth and allow them to switch off their highly pollutive auxiliary diesel engines. A quantitative calculation of a progressive implementation of shore power was undertaken. Although the quantitative analysis undertaken here is clearly limited in that it used only an 8,200 TEU containership in the calculations, this type of ship commonly calls at Kaohsiung port more than any other and is a commonly used size of containership. Moreover, the results provide a context for future studies that could be undertaken with other types of ship as a means of adding to the field. In addition, the results from this analysis showed that, over time, shore power would create emission benefits and improve the socioeconomic conditions for workers and for those living in and around the port area. Yet, the costs of initial set up and installation/maintenance are so high that to introduce it is currently highly expensive, and thus not something that is being done. Parallels can be drawn with other ports elsewhere (e.g. in Europe (Arduino et al, 2011) and with other policies such as the retrofitting of ships engines for LNG (Acciaro, 2014). Complementing this quantitative data, in-depth qualitative data from interviews with key stakeholders show, significantly, that, even though almost everyone was in favor of shore power and were aware of its environmental and socioeconomic benefits (cf. Hall, 2010; Theodoros, 2012), the costs of introduction are considered prohibitive. Its introduction would thus require a conscious legislated policy drive from the Taiwanese government, perhaps similar to those that have led its introduction elsewhere in the world, and ideally as part of a coordinated energy management policy (Acciaro et al., 2014) or as a flanking measure for wider policy concepts 
(Wilmsmeier, 2012). Without this conscious legislated policy drive shore power may well not be implemented, as is the case in many European ports (Adamo et al. 2014).

Indeed, our data showed that many issues remain uncertain: voltages; connectors; connection lag times. Procedurally, the aspect of balancing the need to have a wide impact with the need to start somewhere; the aspect of wanting to start to introduce shore power but to remain competitive globally, and the issue of needing to establish effective communication between the different departments. The government officials and port operators we interviewed were split between the ideas that shore power would be 'inevitable' yet that without establishing a 'convention' for it, shore power would not be used even if facilities existed. Although a desire for shore power clearly exists, and the importance of following the 'international green port trend' is recognized and concurred with, the set up cost is extremely high, and the decision to introduce it is thus too large a one to be made at a level less than a national government one. Further, as our data also showed, there is a perceived lack of clarity amongst government officials regarding which department would be responsible.

The managerial perspective is thus a key one that will need careful approach and thorough planning. The sensitivity of electricity pricing, of responsibility for the cost of shore power, of balancing the needs of different stakeholders, of co-ordinating different departments, and of carefully managing a cultural change toward using shore power are all key issues. They are also highly complex issues that will require any introduction of shore power to be managed extremely effectively in order for it to succeed and to attain port sustainability whilst at the same time maintaining port profitability.

Thus, to end with an answer to the question of whether to introduce shore power, the answer has to be 'Yes', but at the moment also 'No'. 'Yes', in the sense that it would improve efficiency and the socioeconomic and health related environment of the port over time, and also create economic savings as well; 'No' in the sense that the initial cost is so high that it would need to be carried by legislation and by the government in order to absorb it and not discourage trade. In this vein, one fruitful area of future research we believe would be to interview key participants in the areas where shore power has been introduced to gather their experiences on how this was done. In Taiwan at the moment, and in the port of Kaohsiung, similarly to the situation in many ports elsewhere, shore power offers much potential and many benefits, but as yet the commitment to introduce it is not strong enough or concerted enough to do so. Will it then be introduced? We hope 'Yes', but have to at the moment 
conclude 'No'.

\section{Acknowledgements}

Financial support for this research was provided by National Research Council, Taiwan (NSC 101-2410-H-424-015) and Feng Chia University, Taiwan (14I42308).

\section{References}

Acciaro, M., Vanelslander, T., Sys, C., Ferrari, C., Roumboutsos, A., Giuliano, G., Lam, J.S.L. \& Kapros, S. (2014). Environmental sustainability in seaports: a framework for successful innovation. Maritime Policy \& Management, 41(5), 480-500.

Acciaro, M., Ghiara, H., \& Cusano, M. I. (2014). Energy management in seaports: A new role for port authorities. Energy Policy, 71, 4-12.

Acciaro, M. (2014). A real option application to investment in low-sulphur maritime transport. International Journal of Shipping and Transport Logistics, 6(2), 189-212.

Adamo, F., Andria, G., Cavone, G., Capus, C.D., Lanzolla, A.M.L., Morello, R., \& Spadavecchia, M. (2014). Estimation of ship emissions in the port of Taranto, Measurement, 47, 982-988.

Arduino, G, Carillo Murillo, D.G., \& Ferrari, C. (2011). Key factors and barriers to the adoption of cold ironing in Europe, working papers SIET 2011-ISSN 1973-3208.

Bakhtin, M. M., \& Holquist, M. (1981). The dialogic imagination: Four essays. Austin: University of Texas Press.

Berechman, J., \& Tseng, P.H. (2012). Estimating the environmental costs of port related emissions: the case of Kaohsiung, Transportation Research Part D: Transport and Environment, 17(1), 35-38.

Browning, K., \& Bailey, K. (2006). Current methodologies and best practices for preparing port emission inventories, in: $5^{\text {th }}$ International Emission Inventory Conference, New Orleans, May 15-18, 2006.

Chang, C.C., \& Wang, C.M. (2012). Evaluating the effects of green port policy: Case study of Kaohsiung harbor in Taiwan, Transportation Research Part D: Transport and Environment, 17(3), 185-189.

Charmaz, K. (2011). Grounded Theory Methods in Social Justice Research. In Denzin, N.K., \& Lincoln, Y.S. (Eds). The Sage handbook of qualitative research. Thousand Oaks, Calif: Sage. 359-380.

Christians, C.G. (2011). Ethics and politics in qualitative research. In Denzin, N.K., \& Lincoln, Y. S. (Eds). The Sage handbook of qualitative research. Thousand Oaks, Calif: Sage. 61-80.

Commission Recommendation 2006/339/EC, on the promotion of shore-side 
electricity for use by ships at berth in community ports, Official Journal of the European Union, 8 May 2006

Cortazzi, M., Pilcher, N., \& Jin, L. (2011). Language choices and 'blind shadows': investigating interviews with Chinese participants. Qualitative Research, 11(6), 505-535.

Ericsson, P., \& Fazlagic, I. (2008). Shore power supply, Master of Science Thesis, Chalmers University of Technology, Goteborg Sweden.

Ferrara, P.J., Uva, M.A., \& Nowlin, J. (2011). Naval ship-to-shore high temperature superconducting power transmission cable feasibility, IEEE Transactions on Applied Superconductivity, 21(3), 984-987.

Galasiński, D., \& Kozłowska, O. (2010). Questionnaires and lived experience: Strategies of coping with the quantitative frame. Qualitative Inquiry, 16(4), 271-284.

Gilbert, P., \& Bows, A. (2012). Exploring the scope for complementary sub-global policy to mitigate $\mathrm{CO}_{2}$ from shipping, Energy Policy, 50, 613-622.

Hall, W. (2010). Assessment of $\mathrm{CO}_{2}$ and priority pollutant reduction by installation of shore power, Resources, Conservation and Recycling, 54, 462-467.

Holstein, J.A., \& Gubrium, J.F. (1995). The active interview. Thousand Oaks, CA: Sage.

Jia-Sheng, L.I., Jiang, L.J., Qiu, B., \& Yang, W.M. (2012). Electronic shore power station based on matrix-style frequency algorithm, Physics Procedia, 24, 932-937.

Jill, B.B., Ibrahim, M. Leong, T., Prevost, D., Sandifur, M., \& Sinkoff, R. Port of Oakland completes shore power project's first phase, Port Technology International, http://www.porttechnology.org/

Joseph, J., Patil, R.S., \& Gupta, S.K. (2009). Estimation of air pollutant emission loads from construction and operational activities of a port and harbour in Mumbai, India. Environmental Monitoring and Assessments, 159, 85-98.

Khersonsky, Y., Islam, M., \& Peterson, K. (2007). Challenges of connecting shipboard marine systems to medium voltage shoreside electrical power, IEEE Transactions on Industry Applications, 43(3), 838-844.

Kim, J., Rahimi, M., \& Newell, J. (2012). Life-cycle emissions from port electrification: a case study of cargo handling tractors at the port of Los Angeles, International Journal of Sustainable Transportation, 6, 321-337.

Ko, T.T., \& Chang, Y.C. (2010). Integrated marine pollution management: a new model of marine pollution prevention and control in Kaohsiung, Taiwan, Ocean \& Coastal Management, 53(10), 624-635.

Lam, J.S.L., \& Notteboom, T. (2014). The Greening of Ports: A Comparison of Port Management Tools Used by Leading Ports in Asia and Europe, Transport Reviews, 
34(2), 169-189.

Liu, T.K., \& Tsai, T.K. (2011). Vessel traffic patterns in the Port of Kaohsiung and the management implications for preventing the introduction of non-indigenous aquatic species, Marine Pollution Bulletin, 62(3), 602-608.

Liu, T.K., Sheu, H.Y., \& Tasi, J.Y. (2014). Sulfur dioxide emission estimates from merchant vessels in a port area and related control strategies, Aerosol and Air Quality Research, 14(1), 413-421.

Ministry of Transportation and Communication. http://www.motc.gov.tw/en/

Ng, A.K.Y., \& Song, S. (2010). The environmental impacts of pollutants generated by routine shipping operations on ports, Ocean \& Coastal Management, 53(5-6), 301-311.

Pilcher, N., Smith, K.L., \& Riley, J. (2013). International students’ first encounters with exams in the UK: superficially similar but deeply different. International Journal of Teaching and Learning in Higher Education, 25(1), 1-13.

Qu, S.Q., \& Dumay, J. (2011). The qualitative research interview. Qualitative Research in Accounting \& Management, 8(3), 238-264.

Salomon, M. (2009). Recent European initiatives in marine protection policy: toward lasting protection for Europe’s seas? Environment Science \& Policy, 12(3), 359-366.

Svedung, I., \& Rasmussen, J. (2002). Graphic representation of accident scenarios: mapping system structure and the causation of accidents. Safety Science, 40(5), 397-417.

Taiwan International Port Corporation. http://163.29.117.5/english/index.htm

Theodoros, P.G. (2012). A cold ironing study on modern ports, implementation and benefits Thriving for Worldwide Ports, Master Thesis, School of Naval Architecture \& Marine Engineering, National Technical University of Athens, Greece.

Transportation Research Statistics, Taiwan http://www.iot.gov.tw/

Trozzi, C., \& Vaccaro, R. (1998). Methodologies for estimating air pollutant emissions from ship, Technical Report MEET RF98b.

Vergara, J., McKesson, C., \& Walczak, M. (2012). Sustainable energy for the marine sector, Energy Policy, 49, 333-345.

Vermeer H.J. (2004). Skopos and commission in translational action. In: Venuti L (ed.) The Translation Studies Reader (2nd ed.). London: Routledge, 221-232.

Voloshinov, V. N., Matejka, L., \& Titunik, I. R. (1973). Marxism and the philosophy of language. New York: Seminar Press.

Wilmsmeier, G. (2012). Infrastructure charges: Creating incentives to improve environmental performance. Bulletin Fal. No. 309 - 5/2012.

Wilmsmeier, G., Froese, J., Zotz, A. \& Meyer, A. (2014). Energy Consumption and 
Efficiency - Emerging Challenges from Reefer Trade in South American Container Terminals. Working Paper DRNI, ECLAC, Santiago, Chile.

Yang, X., Bai, G., \& Schmidhalter, R. (2011). Shore to ship converter system for energy saving and emission reduction, $8^{\text {th }}$ International Conference on Power Electronics-ECCE Asia, May 30-June 3, 2011, The Shilla Jeju, Korea.

Yap, W.Y., \& Lam, J.S.L. (2013). 80 million-twenty-foot-equivalent-unit container port? sustainable issues in port and coastal development, Ocean \& Coastal Management, 71, 13-25.

Yeh, Y.S., Chiu, Y.F., Chen, K.C., Ko, J.L., Lu, J.C. (2013). Cost-benefit evaluation for the usage of high volt shore power in the container terminal of Kaohsiung Port, Proceedings of the 35 ${ }^{\text {th }}$ Ocean Engineering Conference in Taiwan, November 21-22, 2013, National Sun Yat-sen University, Kaohsiung City, Taiwan.

Zis, T., North, R.J., Angeloudis, P., Ochieng, W.Y., \& Bell, M.G.H. (2014). Evaluation of cold ironing and speed reduction policies to reduce ship emissions near and at ports, Maritime Economics \& Logistics, 16(4), 371-398.

\section{Appendix A: Issues for discussion with regard to shore power systems Prior to introducing Shore Power}

- List, and then involve, all stakeholders in discussion

- Use the discussion to decide whether shore power is desired and feasible

- Gather data on pricing systems where shore power exists (e.g. ports in the States)

- Decide which government departments will be responsible for introducing and regulating shore power.

- Consider technical solutions to issues of voltage, connection types, set up times, and others.

- Decide on whether to subsidize and if so how, and to what extent to subsidize

- Consider funding shore power through initiatives such as emissions taxes

- Consider how to regulate and also to what extent regulation should be the driving force behind the introduction of shore power.

- Consider how strict regulations should be and to whether to introduce 'sunset' type clauses to force ships to adopt shore power.

- Within the context of the above, and through the use of quantitative means, calculate a pricing for the electricity costs of shore power.

\section{During the implementation of shore power}

- Consider how to publicize the use of shore power, and to justify its introduction. 
- In order to help achieve green port, consider the implementation of shore power within the wider context of other initiatives such as emissions tax policies.

- Consider and map out the implementation of shore power in both geographical stages (port by port) and also temporal stages (year by year) so it is phased in gradually.

- Establish bodies to carefully monitor the impact of shore power on port competitiveness and overall green port trends.

Appendix B: Spider diagrams

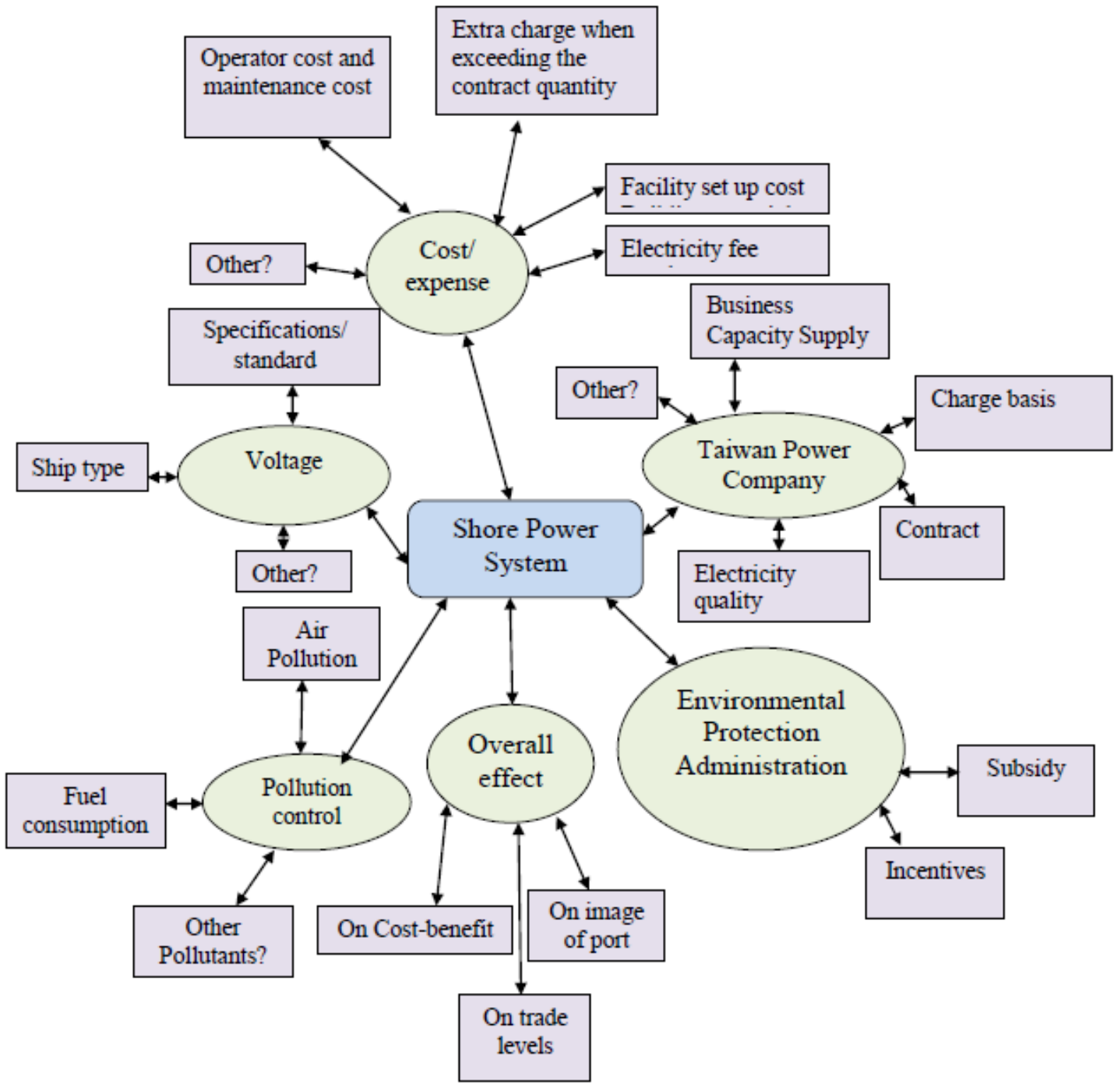

